\title{
South African Farmers' Needs of Agricultural Data
}

\section{J A Groenewald}

Department of Agricultural Economics, University of the Free State

\section{A Frick}

Uni Grain Trading Company and University of the Free State

\section{ABSTRACT}

Data on agriculture are required by decision-makers, including farmers, to solve problems and make business decisions. The needs of decision-makers have changed over time. Since information systems are designed to aid decisionmakers, their needs should be determined. A mail survey among farmers indicated that they are chiefly interested in information regarding producer prices, prices of field crop inputs and statistics on imports and exports of livestock products. There is also interest in employment data and statistics on economic, institutional and infrastructural matters.

JEL N 57

\section{INTRODUCTION}

It is generally accepted that farmers, like all other business people, become increasingly dependent on data and information for the functioning of their businesses in a globalising, increasingly information based economy and society. This is true, irrespective of whether information or data is needed for long-, medium- or short-term decision-making. However, different types of data are needed for different types of decisions and for different decision-making terms.

In most countries that have succeeded to achieve rapid technical progress and growth in agriculture, the socialisation of agricultural research and extension has been deliberately employed as an instrument to modernise agriculture (Hayami \& Ruttan, 1985: 87). Governments have also accumulated data and processed information, both for purposes of their own policy formation and for informing entrepreneurs about the nature of their environment. This has been done with respect to all economic sectors, including agriculture. However, despite the long history of government involvement in agriculture and acknowledgement of the 
need for accurate and valid data, there is a lack of documented evidence on the actual requirements of those who need agricultural data (Bamard, 1979: 74; Russel, 1983: 40).

\section{THE AGRICULTURAL INFORMATION SYSTEM}

\subsection{Terminology}

The terms data and information are often used interchangeably. However, they refer to two different, although closely related concepts.

The common but confused vocabulary which erroneously equates data with information fails to distinguish between the different steps in the process by which data and information are produced (Bonnen, 1975: 754). The terms data and information are discussed first.

Data are a symbolic representation of concepts, quantities which are the direct product of measurement or counting (Bonnen, 1975: 754). Larson and Narain (1998: 3) define data as given facts about a place, person or thing, for example, the production or price of a commodity. However, in real statistical terms, output, prices or inter-industry flows are certainly not independent of the statistical operations involved in their measurement. These data are constructed by means of statistical measures that are operationally meaningful through various levels of aggregation, valuation, basic units or counts and weighting schemes that are determined against a theoretical background and with some analytical aim in mind. Data on agriculture can be classified as market or structural data (Just, 1983: 872-81). Market data consists of data on price, acreage, production, livestock numbers, stocks, consumption and exports, while structural data include data on income, employment, productivity, nutrition and distribution of resources.

Information however involves more than data. It usually combines data from various collection processes and subject matters, always within some analytical interpretation (Bonnen, 1975: 755); it results from modelling, formatting, organising or converting data in a way that increases the level of knowledge and its usefulness for the user (Burch et al., 1974: 4 cited in De Waal \& Van Zyl, 1991: 284). Information is data endowed with relevance and purpose. Converting data into information requires knowledge (Drucker, 1990: 202, 203). Information can be technical, commercial (including marketing information), social and cultural and also legal information (Aina, 1995: 1-11). 


\subsection{The Agricultural Information System}

An agricultural information system is a logical configuration of significant information for problem solving and decision-making in agriculture (Eisgruber, 1967: 1541-52). The system is a product of some basic process of enquiry which classifies and gives meaning to data (Barnard, 1975: 294); data only become information after the required analysis and interpretation are made by the decision-makers (Riemenschneider \& Bonnen, 1979:149) or by analysts for use by decision-makers.

An appropriately designed information system should therefore reduce uncertainty and manage undesired consequences (Bonnen, 1975: 759; FAO, 1986: 4, 5) and aid in the interpretation of the complexity of agriculture (FAO, 1986:4). Vlasin et al. (1975: 900-09) specify three purposes of data and information systems, namely (1) reacting to past problems and planning for present concerns, (2) responding to predicted future scenarios and planning towards the future and (3) planning for and creating a desired future. The information system contains three elements: (1) a data system, (2) an information system which includes the analytical capability necessary to transform data into information and (3) the decision-makers.

\subsubsection{The data system}

Every data system involves an attempt to represent reality by describing empirical phenomena in some system of categories usually in quantified form (Bonnen, 1975: 755; Riemenschneider \& Bonnen, 1979: 147). Since reality appears infinitely complex and is not reality grasped by the human mind, it is necessary first to break down phenomena into a set of categories or classes that lend themselves to measurement. Data are the result of counting or measurement. This presupposes a concept. Concepts are abstract and cannot be measured directly. Operational definitions are then devised to represent the concepts, and these are measurable.

\subsubsection{The information system}

Data are rarely directly used in the raw form by decision-makers (Bonnen, 1975: 760; Eisgruber, 1967: 1543; Drucker, 1990: 202). Data must be transformed into information before it has much utility; information processing systems are therefore necessary (Riemenschneider \& Bonnen, 1979: 149). Beside the production of data, the system involves the analysis and interpretation of the data in some purposeful decision or problem solving context. Data are transformed by intervening acts of interpretation, that is, through statistical and economic analysis, policy and political evaluation etc., to place them in the 
context of specific problem and thus make the data meaningful to a particular decision-maker. An information system should include not only a data system but also the analytical and other means necessary to interpret the data (Bonnen, 1975: 760). Any theory of information must have a multidisciplinary perspective to be useful in understanding information systems (Eisgruber, 1967: $1541-43)$.

\subsubsection{The decision-makers}

Information systems in agriculture are designed to help public and private decision-makers make decisions designed to solve problems that arise at the farm, firm, industry or national economy level (Riemenschneider \& Bonnen, 1979: 150). The goals and values of the decision-makers must impact on the design of the information system, since these goals and values provide insight into the nature of the problem on which the system focuses. Therefore, the objectives of an information system should be viewed in the context of decisionmaking (Barnard, 1979: 75), problem solution (Eisgruber, 1967: 1544; Barnard, 1979: 76) and knowledge (Gardner, 1975: 895 and Juster, 1973: 139-40). In order to achieve these objectives, the system needs to take into account the entire range of economic, social and other information at the household, firm, local, regional, national and even international level (Eisgruber, 1967: 1540). However, information designed for farm policy decisions by government policymakers would differ from information used by a farmer in the day-to-day operation of a farm business; there are different categories of decision-making (Riemenschneider \& Bonnen, 1979: 152).

\subsection{The Supply of Agricultural Data}

Primary data (also called raw, basic or unprocessed data) spring from three main sources: experimental sources, farms and a miscellany of other organisations related to the agricultural sector, such as government departments, markets, marketing boards and commercial firms (Barnard, 1975: 291). Data are obtained either by experimental or non-experimental means (Barnard, 1975: 303). The former rely heavily on testing relationships between phenomena by eliminating or controlling as many extraneous variables as possible, and apply mainly to natural and biological science. By contrast, the latter depend largely on various forms of censuses and surveys (Barnard, 1975: 304; USDA, 1987: 7 and FAO, 1986: 4) and farm account projects (Plaunt, 1967: 1529).

\subsection{Agricultural Data in South Africa}

This paper deals with only non-experimental means of data collection. The collection of market data on South African agriculture began in 1915 with a 
system of monthly crop and livestock reports by the Department of Agriculture. Structural and market data on agriculture were included in the population census of 1904 and the agricultural and population census of 1911. The data sources were initially samples of evenly distributed farmers in various districts and reports of livestock inspectors and other officials of the Department. Later in the early $1920 \mathrm{~s}$, the districts were divided as far as practicable into small areas of four farms, with one farmer being appointed as a crop respondent (Department of Agriculture, 1922: 1-3). The crop respondent had to complete a monthly report, which normally included livestock and crop conditions. This report was forwarded to the Magistrate of that district where it was processed, scrutinised, weighted and averaged before transmission to Pretoria. Since the system depended on the farmers as a source of data, the Government in retum had to keep the farmers well informed with related information that was in turn estimated from the data the farmers supplied. The estimates were subsequently validated by agricultural censuses and surveys, conducted by the Department of Census (Department of Agriculture, 1907-1927).

The late 1930s and 1940s were characterised by the establishment of control boards, which regulated the marketing of the most important agricultural products in South Africa. Statutory measures (Article 52 of the Marketing Act) enabled marketing boards to collect data by means of compulsory returns. These data supplied by the marketing boards, came to be regarded as reliable sources by decision-makers. As a result, the system of crop and livestock reports was reduced to only forecasts and final estimates of summer and winter field crops, and estimates of livestock numbers. Agricultural censuses and surveys were valuable sources of structural as well as benchmark data for crop forecasts and livestock number estimates. However, problems were encountered with the inconsistency of definitions (Nieuwoudt, 1973: 20), the discrepancies between census data and other official data sources (Groenewald, 1989:90) as well as delayed publishing dates.

The deregulation of marketing in the 1990 s was characterised by the disbandment of marketing boards, resulting in a decrease and in some cases, the discontinuation of the supply of administrative data (Willemse, 1996: 3). For some products like grain and oilseeds, cotton, deciduous, citrus, dried and canned fruit, luceme, wool, mohair, milk and meat, alternative organisations were established under the Marketing of Agriculture Products Act of 1996 to continue with the collection of agricultural data (National Agricultural Marketing Council, 1998). However, these organisations still rely on compulsory or in some cases on voluntarily returns for the collection of data. Budgetary constraints also led the Central Statistical Service (now Statistics South Africa) to postpone the agricultural census planned for 1998. A dearth of available data relative to needs may be expected in the future. 


\subsection{Users of Agriculture Data}

Anyone who is in business with a profit objective - without which no business is sustainable - has to identify existing and potential markets, the requirements and rules of these markets and prices that can be realised on these markets. The same principle still applies although much of agricultural information is subsidised and provided to the user free of charge (Metcalfe, 1989: 114). The most meaningful classification of users of agricultural data appears to be one as policy-makers, researchers, agricultural service industries, farmers and extension offices (Aina, 1995: 1-11; Plaunt, 1967: 1531; Russel, 1983: 45-6). Farmers represent both the beginning and the end of the data-and-information chain. Seen from the perspective of management theory, one would expect farmers to demand both technical and marketing information. This information, if required, will dictate the nature and extent of raw data requirements. The remainder of this paper will be devoted to an attempt to determine the data and information needs felt by farmers in South Africa. Only if these needs, together with those of the other user groups are satisfied, will the official data collection and dissemination branches of officialdom be able to claim success in meeting their main task.

\section{RESEARCH APPROACH}

Mail surveys were used to determine the needs of three categories of agricultural data users: Agribusinesses, researchers and farmers. The rest of this article discusses the results obtained from the farmers. Mail surveys have previously been used to determine agricultural data needs in other countries too, for example, the USA (Ebling \& Ahlgren, 1954: 1226-39; Blanch, 1955: 1038-46; American Agricultural Economics Association Committee on Economic Statistics, 1972: 1072) and New Zealand (New Zealand, 1998: 10). Some studies were also done in South Africa by the Bureau of Financial Analysis of the University of Pretoria (1990) regarding fresh product markets, the Department of Agriculture (1992) and, on a more limited scale, the South African Agricultural Union (Du Toit, 1999).

Since there is no complete list of the farming population, a sampling frame as described by Scheaffer $e t$ al., (1990: 111-20) was constructed. Addresses were obtained from the Decidious Producer Trust, the National Crop Estimates Committee and some other organisations which supplied addresses conditional on anonymity. A total number of 17300 addresses was thus obtained. Farmers were, for this purpose, stratified into three main groups, namely producers of field crops, horticultural products and livestock. In an effort to obtain 100 sampling units for each of the three main groups, and assuming a response of 50 
per cent, it was decided to include 600 farmers in the sample. The systematic sampling method was used. The questionnaires consisted of four sections. Firstly an introduction, containing questions on characteristics of the sampling units. The second section was concerned with the need for current statistics. It contained questions on the priority and frequency of need of statistics pertaining to field crops, horticulture and livestock. Questions were also asked concerning forecasts, sources and types of decision for which statistics are needed. A third section of the questionnaire was concerned with the need for basic statistics. The question type was similar to that of the second section. A fourth section was concerned only with statistics supplied by the National Department of Agriculture; these results are not discussed in this paper.

\section{RESULTS}

\subsection{Introduction}

From the 600 questionnaires sent out, 105 were received back. Of these, 99 were used in the analysis. Taking into account 17 undelivered questionnaires, this means a response rate of 18 per cent. Farmers in general tend to have a low response rate to questionnaires and although the response rate is disappointing, it is still acceptable. It does, however, also indicate low interest in statistical data. Of the 99 respondents, 42.7 per cent were older than 50 years, 34.4 per cent between 41 and 50 years and the remaining 22.9 per cent younger than 40 years. The majority, 63.5 per cent, had had more than 12 years of school education (including tertiary education such as diplomas or degrees); the remaining had had between 7 and 12 years school education. Full-time farmers represented 89.6 per cent of the respondents.

\subsection{The Need for Current Statistics}

\subsubsection{Field crops}

The need for current statistics on field crops is summarised in Table 1. Producers' prices and prices of production inputs are indicated by 60 per cent and more of the respondents as very important. Utilisation of products and area planted to perennial crops are desired by fewer than 30 per cent of the respondents. The statistics needed are mostly yearly, while statistics on stock of products, volume of production and consumption are needed quarterly. Prices of production inputs and quantity of import and exports are needed monthly while producer prices are needed weekly. The need for producer prices on a weekly basis could be due to both volatile prices and the readily availability of 
prices of maize, wheat and sunflower on the South African Future Exchange (SAFEX).

The statistics, on average, are mostly wanted on the national level (61.8 per cent of the respondents). In order of importance, statistics are wanted for maize, wheat, sunflower, soybeans and dry beans.

\section{Table 1 The need for current statistics by farmers - Field crops}

\begin{tabular}{|c|c|c|c|c|c|}
\hline \multirow[t]{2}{*}{ Item } & \multirow{2}{*}{$\begin{array}{c}\text { Priority } \\
\text { Very } \\
\text { important }\end{array}$} & \multicolumn{4}{|c|}{ Frequency } \\
\hline & & Yearly & Quarterly & Monthly & Weekly \\
\hline Producer prices & $69.2 \%$ & $20.0 \%$ & $14.5 \%$ & $21.8 \%$ & $43.6 \%$ \\
\hline \begin{tabular}{|l|l|}
$\begin{array}{l}\text { Prices of production } \\
\text { inputs }\end{array}$ \\
\end{tabular} & $61.5 \%$ & $28.3 \%$ & $26.4 \%$ & $34.0 \%$ & $11.3 \%$ \\
\hline Cost of production & $8 \%$ & $34.6 \%$ & $26.9 \%$ & $30.8 \%$ & $7.7 \%$ \\
\hline $\begin{array}{l}\text { Quantity of imports and } \\
\text { exports }\end{array}$ & $55.1 \%$ & $18.2 \%$ & $20.0 \%$ & $38.2 \%$ & $23.6 \%$ \\
\hline Yield forecasts & $.7 \%$ & $38.5 \%$ & $25.0 \%$ & $28.8 \%$ & $7.7 \%$ \\
\hline Stocks of products & $47.7 \%$ & $17.6 \%$ & $41.2 \%$ & $31.4 \%$ & $9.8 \%$ \\
\hline Volume of production & $46.9 \%$ & $34.6 \%$ & $34.6 \%$ & $23.1 \%$ & $7.7 \%$ \\
\hline $\begin{array}{l}\text { Area planted to annual } \\
\text { crops }\end{array}$ & $44.6 \%$ & $28.8 \%$ & $28.8 \%$ & $36.5 \%$ & $5.8 \%$ \\
\hline $\begin{array}{l}\text { Consumer prices of } \\
\text { products }\end{array}$ & $1 \%$ & $20.8 \%$ & $30.2 \%$ & $22.6 \%$ & $26.4 \%$ \\
\hline $\begin{array}{l}\text { Value of imports and } \\
\text { exports }\end{array}$ & $43.1 \%$ & $28.3 \%$ & $28.3 \%$ & $22.6 \%$ & $20.8 \%$ \\
\hline Area harvested estima & & $52.9 \%$ & $13.7 \%$ & $25.5 \%$ & $7.8 \%$ \\
\hline Consumption of products & $32.3 \%$ & $35.8 \%$ & $37.7 \%$ & $22.6 \%$ & $3.8 \%$ \\
\hline $\begin{array}{l}\text { Area planted to perennial } \\
\text { crops }\end{array}$ & $26.2 \%$ & $50.0 \%$ & $34.8 \%$ & $10.9 \%$ & $4.3 \%$ \\
\hline Utilisation of products & $24.6 \%$ & $36.0 \%$ & $40.0 \%$ & $22.0 \%$ & $2.0 \%$ \\
\hline
\end{tabular}

\subsubsection{Horticulture}

The listed results (see Table 2) indicate that 65.5 per cent of the respondents regard producer prices as very important. Utilisation of products and area planted to annual crops seem not as important, with only 24.1 and 26.7 per cent of the respondents, respectively, regarding these as very important. The statistics wanted are mostly yearly; however, consumption and utilisation of products are wanted quarterly, stocks of products and quantity of import and 
export are needed monthly and producer and consumer prices of products weekly.

The statistics, on average, are mostly needed on the national level ( 50.3 per cent of the respondents) while statistics on a provincial level are desired by 23.1 per cent of the respondents. The statistics needed are for deciduous and other summer fruits, viticulture, citrus and subtropical fruits and vegetables.

Table 2 The need for current statistics by farmers - Horticulture

\begin{tabular}{|c|c|c|c|c|c|}
\hline \multirow[t]{2}{*}{ Item } & \multirow{2}{*}{$\begin{array}{c}\text { Priority } \\
\text { Very } \\
\text { important }\end{array}$} & \multicolumn{4}{|c|}{ Frequency } \\
\hline & & Yearly & Quarterly & Monthly & Weekly \\
\hline Producer prices & $65.5 \%$ & $27.6 \%$ & $20.7 \%$ & $20.7 \%$ & $31.0 \%$ \\
\hline Volume of production & $51.7 \%$ & $40.7 \%$ & $18.5 \%$ & $29.6 \%$ & $11.2 \%$ \\
\hline Stocks of products & $51.7 \%$ & $11.5 \%$ & $26.9 \%$ & $34.6 \%$ & $27.0 \%$ \\
\hline Consumer prices of products & $48.3 \%$ & $25,9 \%$ & $14.8 \%$ & $29.6 \%$ & $29.7 \%$ \\
\hline Cost of production & $48.3 \%$ & $40.7 \%$ & $25.3 \%$ & $22.5 \%$ & $11.5 \%$ \\
\hline Yield forecasts & $44.8 \%$ & $55.6 \%$ & $25.9 \%$ & $7.4 \%$ & $11.1 \%$ \\
\hline Prices of production inputs & $44.8 \%$ & $37.0 \%$ & $25.9 \%$ & $25.9 \%$ & $11.2 \%$ \\
\hline Consumption of products & $44.6 \%$ & $22.2 \%$ & $33.3 \%$ & $29.6 \%$ & $14.9 \%$ \\
\hline $\begin{array}{l}\text { Area planted to perennial } \\
\text { crops }\end{array}$ & $41.4 \%$ & $62.1 \%$ & $20.7 \%$ & $17.2 \%$ & $0.0 \%$ \\
\hline $\begin{array}{l}\text { Quantity of imports and } \\
\text { exports }\end{array}$ & $41.4 \%$ & $32.1 \%$ & $17.9 \%$ & $32.1 \%$ & $17.9 \%$ \\
\hline Area harvested estimates & $34.5 \%$ & $59.3 \%$ & $18.5 \%$ & $18.5 \%$ & $3.7 \%$ \\
\hline Value of imports and exports & $31.0 \%$ & $44.0 \%$ & $12.0 \%$ & $32.0 \%$ & $12.0 \%$ \\
\hline \begin{tabular}{|l}
$\begin{array}{l}\text { Area planted to perennial } \\
\text { crops }\end{array}$ \\
\end{tabular} & $26.7 \%$ & $52.2 \%$ & $13.0 \%$ & $30.4 \%$ & $4.4 \%$ \\
\hline Utilisation of products & $24.1 \%$ & $34.6 \%$ & $34.6 \%$ & $23.1 \%$ & $7.7 \%$ \\
\hline
\end{tabular}

\subsubsection{Livestock}

The need for current statistics of livestock is shown in Table 3. Producer prices and quantity of imports and exports are indicated by 60 per cent and more of the respondents as very important. Herd composition, number of animal in feedlots, utilisation of products, and farm slaughter volumes appear to be less important; fewer than 30 per cent of the respondents classified these as very important. Mostly monthly statistics are needed, while producer prices are needed on a weekly basis. 
Statistics are mostly needed on the national level (by 74.4 per cent of the respondents). Statistics on provincial level are needed by 25.8 per cent of the respondents. The products for which the statistics are needed are, in order of importance, cattle and calves, sheep and goats, dairy (including fresh milk), pigs and wool.

\section{Table 3 The need for current statistics by farmers - Livestock}

\begin{tabular}{|l|c|c|c|c|c|}
\hline \multirow{2}{*}{ Item } & Priority & \multicolumn{3}{|c|}{ Frequency } \\
\cline { 2 - 5 } & $\begin{array}{c}\text { Very } \\
\text { important }\end{array}$ & Yearly & Quarterly & Monthly & Weekly \\
\hline Producer prices & $73.2 \%$ & $11.9 \%$ & $20.9 \%$ & $22.4 \%$ & $\mathbf{4 4 . 8 \%}$ \\
\hline $\begin{array}{l}\text { Quantity of imports and } \\
\text { exports }\end{array}$ & $63.4 \%$ & $10.9 \%$ & $26.6 \%$ & $\mathbf{3 2 . 8} \%$ & $29.7 \%$ \\
\hline Consumer prices of products & $54.9 \%$ & $14.1 \%$ & $25.0 \%$ & $\mathbf{3 1 . 0} \%$ & $29.9 \%$ \\
\hline Cost of production & $51.2 \%$ & $20.3 \%$ & $\mathbf{3 2 . 8} \%$ & $28.0 \%$ & $18.9 \%$ \\
\hline Prices of production inputs & $48.8 \%$ & $20.3 \%$ & $29.7 \%$ & $\mathbf{2 9 . 9 \%}$ & 20.18 \\
\hline Value of imports and exports & $46.3 \%$ & $14.5 \%$ & $27.4 \%$ & $\mathbf{3 7 . 1} \%$ & $21.0 \%$ \\
\hline $\begin{array}{l}\text { Livestock numbers by } \\
\text { category }\end{array}$ & $41.6 \%$ & $\mathbf{4 7 . 6 \%}$ & $25.4 \%$ & $20.5 \%$ & $6.5 \%$ \\
\hline Consumption of products & $41.5 \%$ & $17.7 \%$ & $30.0 \%$ & $37.8 \%$ & $14.5 \%$ \\
\hline Abattoir slaughter volumes & $36.6 \%$ & $25.0 \%$ & $20.0 \%$ & $33.3 \%$ & $21.7 \%$ \\
\hline Farm slaughter volumes & $24.4 \%$ & $\mathbf{3 3 . 3} \%$ & $21.1 \%$ & $29.7 \%$ & $15.9 \%$ \\
\hline Utilisation of products & $24.4 \%$ & $\mathbf{3 2 . 2} \%$ & $\mathbf{3 2 . 2 \%}$ & $27.1 \%$ & $8.5 \%$ \\
\hline Number of animals in feedlots & $23.2 \%$ & $32.8 \%$ & $19.7 \%$ & $\mathbf{4 1 . 0} \%$ & $6.5 \%$ \\
\hline Herd composition & $23.2 \%$ & $\mathbf{5 6 . 7 \%}$ & $25.0 \%$ & $16.7 \%$ & $1.6 \%$ \\
\hline
\end{tabular}

\subsubsection{General}

Of the 99 farmers, 89.5 per cent need forecasts. The products for which the forecasts are needed are maize, cattle and calves, sheep and goats, as well as deciduous citrus fruits. Most farmers indicated that they would like to have the data one month after the date of collection ( 45.6 per cent of the respondents), 26.7 per cent of the respondents would settle for 3 months after the date, while 22.2 per cent of the respondents would be satisfied if they received them after 6 months. Sources of statistics include mainly Landbouweekblad, the Internet and also agents and marketers. Farmers indicated their level of confidence in these sources to be between average and good. Decisions made with the aid of statistics include planning, production and marketing. The level of the accuracy required by the respondents are 90 per cent ( 50.6 per cent of the respondents), 80 per cent ( 33.3 per cent) and 70 per cent ( 16.1 per cent of the respondents). 


\subsection{The Need for Basic Statistics}

Basic statistics are next discussed according to the needs of employment, economic and institutional or infrastructural issues. Questions were also asked about statistics on particulars of farmers and basic household matters; however, respondents indicated a very low need for those statistics, which are therefore not discussed further here. The resuits related to the need for basic statistics on employment are listed in Table 4. It appears that none of these statistics is regarded as very important by 60 per cent or more; salary or wage rate and remuneration of employees are regarded as very important by over 40 per cent of the respondents. Number of regular and family workers do not seem to be regarded as important. The statistics are needed yearly.

Table 4 The need for basic statistics by farmers - Employment

\begin{tabular}{|l|c|c|c|c|c|}
\hline \multirow{2}{*}{ Item } & Priority & \multicolumn{4}{|c|}{ Frequency } \\
\cline { 2 - 6 } & $\begin{array}{c}\text { Very } \\
\text { important }\end{array}$ & $\begin{array}{c}10 \\
\text { Yearly }\end{array}$ & $\begin{array}{c}5 \\
\text { Yearly }\end{array}$ & $\begin{array}{c}2 \\
\text { Yearly }\end{array}$ & Yearly \\
\hline Salary or wage rate & $44.9 \%$ & $6.6 \%$ & $6.6 \%$ & $22.4 \%$ & $\mathbf{6 4 . 4 \%}$ \\
\hline Remuneration of employees & $42.7 \%$ & $8.0 \%$ & $6.7 \%$ & $20.0 \%$ & $\mathbf{6 5 . 3 \%}$ \\
\hline $\begin{array}{l}\text { Number of unemployed } \\
\text { workers }\end{array}$ & $33.7 \%$ & $8.8 \%$ & $20.6 \%$ & $20.6 \%$ & $\mathbf{5 0 . 0 \%}$ \\
\hline Number of family workers & $28.1 \%$ & $10.1 \%$ & $21.7 \%$ & $21.7 \%$ & $\mathbf{4 6 . 5 \%}$ \\
\hline Number of regular workers & $24.7 \%$ & $11.1 \%$ & $20.8 \%$ & $19.4 \%$ & $\mathbf{4 8 . 7 \%}$ \\
\hline
\end{tabular}

The need for economic statistics are listed in Table 5. Income from farm activities and value of land are indicated by respectively 53.6 per cent and 52.3 per cent of the respondents as very important. Non-farm expenditure, household expenditure pattern, income from non-farm activities and rent payments do not seem to be regarded as important. The statistics are needed yearly.

The results of the need for institutional and infrastructural matters are listed in Table 6. Methods of marketing is indicated by 50.6 per cent of the respondents as very important. The methods of irrigation, area under irrigation, quantity of land purchased or sold, capital structure, sources of water supply, level of mechanisation and land utilisation do not seem to be regarded as important. The statistics are needed yearly. 
Table 5 The need for basic statistics by farmers - Economics

\begin{tabular}{|c|c|c|c|c|c|}
\hline \multirow[t]{2}{*}{ Item } & \multirow{2}{*}{$\begin{array}{c}\text { Priority } \\
\text { Very } \\
\text { important }\end{array}$} & \multicolumn{4}{|c|}{ Frequency } \\
\hline & & 10 Yearly & 5 Yearly & 2 Yearly & Yearly \\
\hline $\begin{array}{|lll|}\text { Income } & \text { from } & \text { farm } \\
\text { activities } & & \\
\end{array}$ & $53.6 \%$ & $7.7 \%$ & $3.8 \%$ & $23.1 \%$ & $65.4 \%$ \\
\hline Value of land & $52.3 \%$ & $5.2 \%$ & $10.4 \%$ & $20.8 \%$ & $63.6 \%$ \\
\hline Amount of farming debt & $45.5 \%$ & $6.8 \%$ & $9.6 \%$ & $20.5 \%$ & $63.1 \%$ \\
\hline Interest payments & $40.9 \%$ & $8.6 \%$ & $8.6 \%$ & $22.8 \%$ & $60.0 \%$ \\
\hline $\begin{array}{l}\text { Intermediate production } \\
\text { expenses }\end{array}$ & $33.0 \%$ & $8.3 \%$ & $6.9 \%$ & $27.9 \%$ & $56.9 \%$ \\
\hline Rent payments & $29.5 \%$ & $11.8 \%$ & $13.2 \%$ & $20.6 \%$ & $54.4 \%$ \\
\hline $\begin{array}{l}\text { Income from non-farm } \\
\text { activities }\end{array}$ & $21.6 \%$ & $18.8 \%$ & $13.0 \%$ & $26.1 \%$ & $42.1 \%$ \\
\hline $\begin{array}{l}\text { Household expenditure } \\
\text { pattern }\end{array}$ & $17.0 \%$ & $18.8 \%$ & $9.4 \%$ & $32.7 \%$ & $39.1 \%$ \\
\hline Non-farm expenditure & $14.8 \%$ & $18.8 \%$ & $12.5 \%$ & $34.3 \%$ & $34.4 \%$ \\
\hline
\end{tabular}

The statistics are mostly needed on a magisterial district level ( 35 per cent of the respondents). Statistics are also needed on a national level (32.6 per cent of the respondents).

Of the respondents, 46.9 per cent indicated that they need statistics for the commercial sector, while 2.5 per cent indicated a need for the developing sector. The majority, 50.6 per cent, indicated that they need the statistics for both the commercial and developing sectors. Respondents indicated that they mostly need the statistics 6 months after the date of the collection of the data ( 31.8 per cent of the respondents). Among the respondents some indicated that they need the statistics only 1 and 2 years after the date of collection.

The sources of the statistics are mainly media publications, farmer associations and agents. The level of confidence in the sources is between average and good. Decisions that farmers make with the aid of these statistics include planning, marketing, management and business viability. The level of accuracy needed is between 80 per cent ( 44.1 per cent of the respondents) and 90 per cent ( 42 per cent of the respondents). 
Table 6 The need for basic statistics by farmers - Institutional or infrastructural

\begin{tabular}{|l|c|c|c|c|c|}
\hline \multirow{2}{*}{ Item } & Priority & \multicolumn{3}{|c|}{ Frequency } \\
\cline { 2 - 6 } & $\begin{array}{c}\text { Very } \\
\text { important }\end{array}$ & $\begin{array}{c}10 \\
\text { Yearly }\end{array}$ & $\begin{array}{c}5 \\
\text { Yearly }\end{array}$ & Yearly & Yearly \\
\hline Methods of marketing & $50.6 \%$ & $2.8 \%$ & $12.7 \%$ & $25.4 \%$ & $\mathbf{5 9 . 1 \%}$ \\
\hline Access to credit and finance & $40.9 \%$ & $4.2 \%$ & $11.3 \%$ & $21.1 \%$ & $\mathbf{6 3 . 4 \%}$ \\
\hline $\begin{array}{l}\text { Access to training and } \\
\text { development }\end{array}$ & $36.0 \%$ & $6.9 \%$ & $15.3 \%$ & $26.4 \%$ & $\mathbf{5 1 . 4 \%}$ \\
\hline Access to government support & $32.6 \%$ & $7.0 \%$ & $16.9 \%$ & $22.5 \%$ & $\mathbf{5 3 . 6 \%}$ \\
\hline Fertiliser or chemical usage & $31.5 \%$ & $7.5 \%$ & $17.6 \%$ & $32.4 \%$ & $\mathbf{4 2 . 5 \%}$ \\
\hline Pesticides usage & $31.5 \%$ & $7.4 \%$ & $19.1 \%$ & $29.4 \%$ & $\mathbf{4 4 . 1 \%}$ \\
\hline Land utilisation & $27.0 \%$ & $11.8 \%$ & $17.6 \%$ & $29.4 \%$ & $\mathbf{4 1 . 2 \%}$ \\
\hline Level of mechanisation & $27.0 \%$ & $7.2 \%$ & $29.0 \%$ & $23.2 \%$ & $\mathbf{4 0 . 6 \%}$ \\
\hline Sources of water supply & $27.0 \%$ & $9.0 \%$ & $26.9 \%$ & $23.9 \%$ & $\mathbf{4 0 . 2 \%}$ \\
\hline Capital structure & $23.9 \%$ & $7.2 \%$ & $23.2 \%$ & $30.4 \%$ & $\mathbf{3 9 . 2} \%$ \\
\hline $\begin{array}{l}\text { Quantity of land purchased or sold } \\
\text { Area under irrigation }\end{array}$ & $22.5 \%$ & $9.0 \%$ & $19.4 \%$ & $26.9 \%$ & $\mathbf{4 4 . 7 \%}$ \\
\hline Methods of irrigation & $16.9 \%$ & $8.5 \%$ & $31.0 \%$ & $25.4 \%$ & $\mathbf{3 5 . 1} \%$ \\
\hline
\end{tabular}

\section{CONCLUSION}

As mentioned above, the low response rate to the questionnaire survey is an indication of a lack of interest in agricultural statistics by many farmers. This conclusion may to some degree be ameliorated by the apparent satisfaction derived by some respondents from statistics appearing in a popular farming magazine (Landbouweekblad). It is remarkable that the majority of farmers who did respond have had more than high school education. This would suggest that it is mostly the more advanced farmer-operator who feels he can utilise statistics for decision-making. Many of these farmers are likely to belong to the innovator and early-adopter farmer categories.

The respondents in this study showed interest mainly in information regarding producer prices of farm products, prices of inputs for field crop production and in the case of livestock products, statistics on imports and exports. They are also interested in data on employment, economic, institutional and infrastructure matters. 
It would be in South Africa's interest to supply to agricultural entrepreneurs the kind of statistics and business information they feel a need for. Perhaps this survey can be of use to providers of such information.

\section{REFERENCES}

1 AINA, L.O. (1995) "Information and Agriculture in Africa", In: Aina, L.O., A.M. Kaniki J.B. Ojiambo (eds.), Agricultural Information in Africa. London: Third World Information Service Limited.

2 AMERICAN AGRICULTURAL ECONOMICS ASSOCIATION COMMITTEE ON ECONOMIC STATISTICS (1972) "Our Obsolete Data Systems: New Directions and Opportunities", American Journal of Agricultural Economics, 54: 1069-81.

3 BARNARD, C.S. (1975) "Data in Agriculture: A Review with Special References to Farm Management Research, Policy and Advice in Britain". Journal of Agricultural Economics, 26: 289-333.

4 BARNARD, C.S. (1979) "Concepts and Structures", In: Blackie, N.J. \& J.B. Dent (eds.) Information Systems for Agriculture, London: Applied Science Publishers.

5 BLANCH, G.T. (1955) "New Data Requirements by Areas: How Can They Be Met?" Journal of Farm Economics, 37: 1038-46.

6 BONNEN, J.T. (1975) "Improving Information on Agriculture and Rural Life", American Journal of Agricultural Economics, 57: 753-63.

7 BURO VIR FINANSIëLE ANALISE (1990) Inligtingsaangeleenthede met betrekking tot die Bemarking van Varsprodukte in die Republiek van Suid-Afrika, Pretoria: RGN-reeks: Varsprodukte-ondersoek.

8 DE WAAL, G.J. \& VAN ZYL, J. (1991) "Information Systems in Developing Agriculture with Special Reference to Project Management in Ciskei", Agrekon, 30: 282-6.

9 DEPARTEMENT VAN LANDBOU (1992) Ondersoek na die Daarstelling van ' $n$ Nasionale Inligtingstelsel aangaande die Ekonomiese en Finansiële Posisie op Boerderyvlak vir Beleidsdoeleindes, Unpublished report: Pretoria.

10 DEPARTMENT OF AGRICULTURE, (1922) Crops and Markets, 1(2): 1-3.

11 DRUCKER, P.F. (1990) The New Realities, London: Mandarin.

12 DU TOIT, J.P.F. (1999) Minimum Inligtingsbehoeftes van Bedryfsorganisasies en Boere, Pretoria: Suid-Afrikaanse Landbou-Unie.

13 EBLING, W.H. \& AHLGREN, H.L. (1954) "Agricultural Data: Agricultural Data Requirements - National, State and County", Journal of Farm Economics, 36: 1226-39. 
14 EISGRUBER, L.M. (1967) "Micro- and Macro-Analytical Potential of Agricultural Information Systems", Journal of Farm Economics, 49: 1541-52.

15 FAO, (1986) Food and Agricultural Statistics in the Context of a National Information System, Rome: FAO Statistical Development Series, Food and Agricultural Organisation of the United Nations.

16 GARDNER, B. (1975) "Strategies for Long-Run Investment in Rural, Social, and Economics Statistics", American Journal of Agricultural Economics, 57: 892-99.

17 GROENEWALD, J.A. (1989) "Discrepancies in Agricultural Data from Two Official Sources", Agrekon, 28(1): 90.

18 HAYAMI, Y. \& RUTTAN, V.W. (1985) Agriculturat Development, An International Perspective, (revised ed.) Baltimore and London: The Johns Hopkins University Press.

19 JUST, R.E. (1983) "The Impact of Less Data on the Agricultural Economy and Society", American Journal of Agricultural Economics, 65: 872-81.

20 JUSTER, F.T. (1970) "Micro Data, Economic Research and the Production of Economic Knowledge", American Economic Review, 60: 138-48.

21 LARSON, L.O. \& NARAIN, P. (1998) International Standards and Definitions for Agricultural Statistics and Requirements for World Census of Agriculture, Unpublished Paper presented at the Agricultural Statistics 2000 Conference, Washington, D.C., 18-20 March 1998.

22 METCALFE, J.R. (1989) "Strategic Issues in Agricultural Information Determining the Real Needs". Quarterly.Bulletin of IAALD 34(3): 11317.

23 NATIONAL AGRICULTURAL MARKETING COUNCIL, (1998). Press Release Regarding the Status of the Deregulation of the Control Boards. Pretoria: National Agricultural Marketing Council.

24 NEW ZEALAND, (1998) The Review of Agricultural Statistics Report Wellington: Government Statistician.

25 NIEUWOUDT, W.L. (1973) "Data Problems in Agricultural Economic Research", Agrekon, 12(1): 20-26.

26 PLAUNT, D.H. (1967) "Canada's Experience in and Aspirations for a Comprehensive Farm Data System", Journal of Farm Economics, 49: 1526-40.

27 RIEMENSCHNEIDER, C.H. \& BONNEN, J.T. (1979) "National Agricultural Information Systems: Design and Assessment", In: Blackie, J.J., \& Dent, J.B. (eds.) Information Systems for Agriculture, London: Applied Science Publishers. 
28 RUSSEL, H.M. (1983) "Agricultural User Populations and Their Information Needs in the Industrialised World", Quarterly Bulletin of IAALD, 28(2): 40-52.

29 SCHEAFFER, R.L., MENDENHALL, W. \& OTT, I. (1990) Elementary Survey Sampling ( $4^{\text {th }}$ ed.) Califomia: Duxbury Press.

30 UNITED STATES DEPARTMENT OF AGRICULTURE, (1987) Basic Agricultural Survey Statistics and Methods, Washington, DC: National Agricultural Statistic Services, Training Course Material.

31 VLASIN, R.D., LIBBY, L.W. \& SHELTON, R.L. (1975) "Economic and Social Information for Rural America. Priorities for Immediate Improvement". American Journal of Agricultural Economics, 57: 900 909.

32 WILLEMSE, J., (1996) Information in South African Agriculture: Frustrations and Opportunities, Pretoria: AGROCON '96 Conference. 